\title{
Investigation of the fluids influence on change of sandstones collectors mechanical properties during saturation and degassing
}

\author{
Serhii Tynyna ${ }^{1, *}$, and Vasyl Babenko ${ }^{2}$ \\ ${ }^{1}$ Institute of Geotechnical Mechanics named by N. Poljakov of National Academy of Sciences of \\ Ukraine, 49005, Dnipro, Simferopolska Str., 2a, Ukraine \\ ${ }^{2}$ Ukrainian State University of Chemical Technology, 49000, Dnipro, Haharina Ave., 8, Ukraine
}

\begin{abstract}
The article discusses the effect of fluids on the properties of rocks. It is known that surface active environments, including gas, can significantly change the mechanical characteristics of solids. To establish the dependence of the effect of methane on the strength characteristics of rocks, the results of full-scale and laboratory studies are considered. The experiments were carried out on samples of outburst sandstone formation $m_{3}$, taken at a depth of $915 \mathrm{~m}$. Analysis of research results allowed to establish the effect of changes in gas saturation of rocks on their mechanical properties before and after degassing and partial discharge of experimental areas after they have been worked by lavas along $m_{3}$ formation. It has been established that the reason for the increase in drillability and strength of sandstones was their degassing, and not a change in the stress state of the environment. This led to a change in the deformation properties of rocks in gas-saturated and degassed states.
\end{abstract}

\section{Introduction}

In oil, gas, chemical industries, much attention is paid to the search for surface active agents (surfactants) that can change the strength properties of solid environments and materials [1]. Aqueous solutions of surfactants are used to reduce the strength when drilling oil and gas wells. It is known that surface-active environments, including gas, can significantly change the mechanical characteristics of solid bodies [2].

So, the bottomhole and marginal part of coal seams is strengthened during degassing $[2,3]$. A change in the strength of coal by $25-30 \%$ with saturation with methane was confirmed under laboratory conditions $[4,5]$. And the injection of water with surfactant additives into coal seams is one of the ways to control emissions [6].

Outburst sandstones are gas-saturated and differ significantly in composition and structure from coal. Therefore, it is of interest both to develop methods for determining the mechanical characteristics of rock samples in a gas-saturated state, and to study the properties of outburst sandstones during their gas saturation and degassing $[4,7,8]$.

In mine conditions, determination of the strength of sandstones of outburst and outburst-

\footnotetext{
*Corresponding author: haritonroots@gmail.com
} 
safe zones can be obtained by boring, which characterizes the resistance of the massif to destruction and is measured by drilling time per unit length of the well.

\section{Research service}

Areas of western and eastern field haulage drifts of the $m_{3}$ seam within the mine field on the horizon of $915 \mathrm{~m}$ were selected as experimental ones.

The selection of these areas was due to the need for their degassing and partial unloading during the overhaul of the lavas, as well as the fact that 40 sandstone emissions weighing up to 500 tons occurred during the workings.

In the soil of $m_{3}$ seam lies sandstone $m_{2} \mathrm{Sm}_{3}$ with a thickness of 30-40 m at distance of $30 \mathrm{~m}$. The natural gas content of the rocks varies between $0.5-3 \mathrm{~m}^{3} / \mathrm{t}$. The measured gas pressure in the massif reached $8 \mathrm{MPa}$, and the stresses measured by the method of hydraulic fracturing were $35 \mathrm{MPa}$.

At all stages of the experimental work, the degree of gas saturation and the stress state of the massif were controlled.

\section{Methods}

Within the experimental areas covering outburst and outburst-safe zones of sandstone, core wells were drilled before the development of the overlying coal seam began.

To obtain cores, an upgraded BGA-2m machine was used, having an adjustable hydraulic feed, which was reequipped for core drilling.

To exclude the influence of technological factors, the mode of operation of the machine, providing the standard performance, controlled and maintained at a constant level:

- feed force $5 \mathrm{kN}$,

- pressure of compressed air in the pipeline 0.6 MPa,

- pressure 0.2 MPa,

- flushing fluid flow $10 \mathrm{l} / \mathrm{min}$,

- spindle speed $115 \mathrm{rpm}$.

Carbide crowns with a diameter of $76 \mathrm{~mm}$ were used for boring, the replacement of which was carried out through each linear meter of the well after core extraction. By the time of meter boring, the value of drillability and its change along the well length was determined. Boring was carried out across the strike and on the bedding.

Taking samples from those parts of the wells in which the core was not destroyed on the disks, under laboratory conditions, the limits of the compressive strength of the samples and strength coefficient were determined according to the M.M. Protodyakonov's scale.

We established a correlation between strength and drillability. By extrapolation, the strength of rocks was determined from the drillability of those parts of the massif in which the core was destroyed on disks.

In order to analyze the effect of changes in gas saturation of rocks on their mechanical properties, according to field observations, a similar cycle of research was carried out after degassing and partial unloading of experimental areas after they were worked out by lavas along the formation $m_{3}$.

New core wells were drilled within the experimental areas at distance of 1-2 m from previous wells drilled earlier in an intact massif.

After that, a comparative analysis was made. 


\section{Results and discussion}

The relationship between rock drillability and its strength in general form is expressed by the equation of displaced hyperbola with vertical asymptote:

$$
f=f_{m} t_{b} /\left(t_{b}+t_{0}\right),
$$

where $t_{b}$ - rock drillability, $\min / \mathrm{m} ; f_{m}$ - empirical coefficient, constant for a specific type of boring, the value of which is equal to the asymptotic value of the coefficient of the massif's strength; $t_{0}-$ drillability coefficient, equal in value to rock drillability with a strength coefficient $f / 2$. The constant parameters of equation (1) are determined by the least square's method $f_{m}=18, t_{b}=5$.

In this case, by drillability, the strength of outburst sandstones can be determined in those parts of the massif in which the core was divided into disks during the drilling of wells (see Fig. 1, 2 shaded areas).

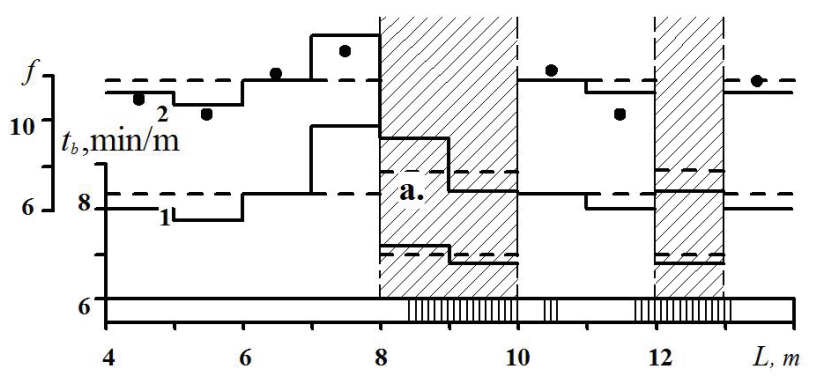

a.

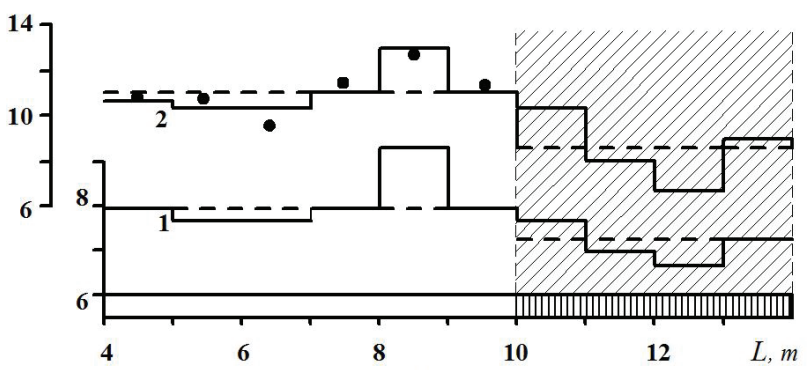

b.

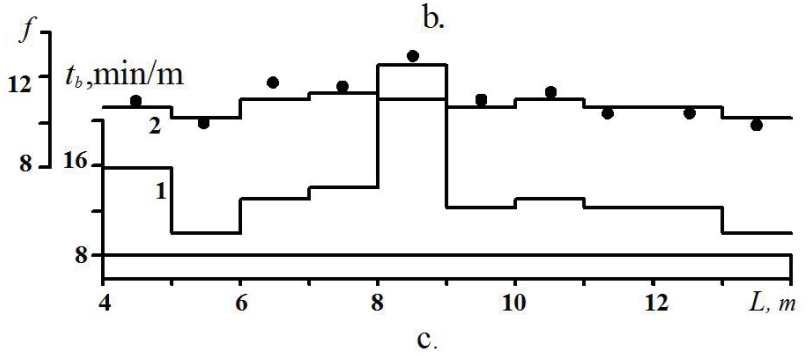

Fig. 1. The nature of change of drillability (1) and strength (2) of sandstone along the length of wells drilled across the strike of rocks in a gas-saturated strained massif $(a, b)$ and after its degassing and partial discharge (c).

The results obtained for wells drilled across the strike of rocks are shown in Figure 1, according to the bedding of rocks in Figure 2.

Figure 1,a and Figure 1,b reflect the patterns of changes in the monitored parameters in the intact massif, the Figure 1,c - after its partial discharge and degassing. 
The abscissa axis shows the distance from the wellhead. The zones in which the cores were divided into disks were shaded for clarity. Polylines 1 reflect the change in drillability along the length of the wells. Its values are averaged over each running meter. Polylines 2 are the rock strength values calculated from the established correlation between drillability and sandstone strength. The dots around lines 2 show the strength values of the corresponding sandstone samples obtained from laboratory tests. Polyline 3 (Fig. 1) corresponds to the change in the modulus of elasticity of rocks along the well length, which was determined by the ultrasonic method by the magnitude of the velocity of the longitudinal and transverse waves.

When comparing the results of laboratory determinations of the coefficients of sandstone strength with the drillability of the corresponding areas shown in Figure 1 and Figure 2, it is clearly seen that the qualitative nature of changes in these parameters along the length of the wells is similar.

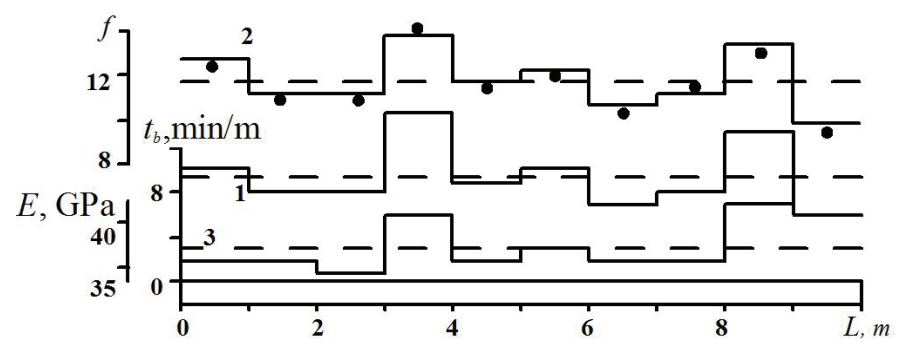

a.

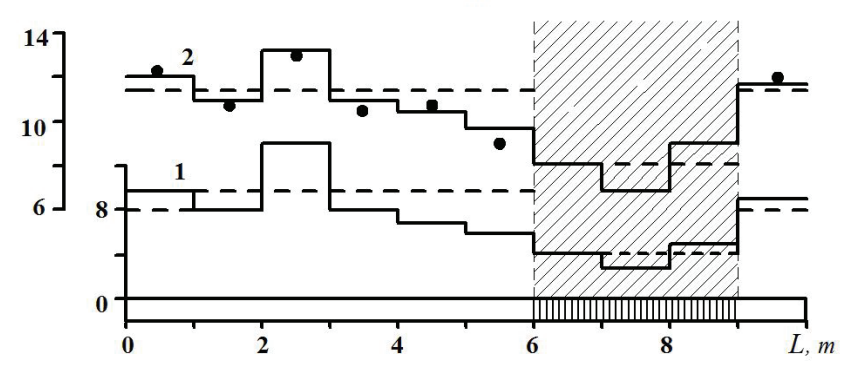

b.

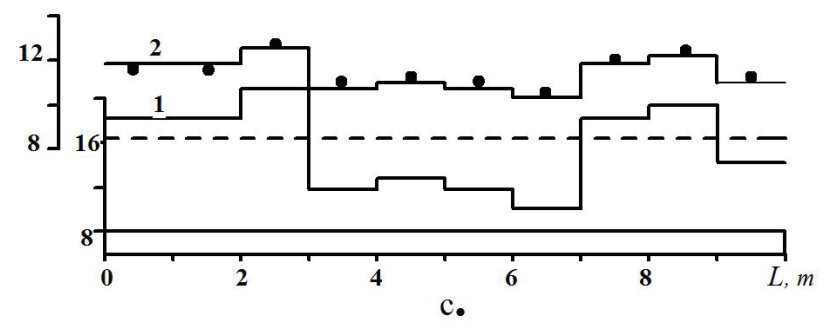

Fig. 2. The nature of changes in drillability (1), strength (2) and elastic modulus (3) of sandstone along the length of wells drilled in the bedding of strained gas-saturated massif $(a, b)$ and after its degassing and partial discharge (c).

Analysis of the results presented in Figure 1 and Figure $2(a, b)$, indicates that the rock drillability varied from 3 to $15 \mathrm{~min} / \mathrm{m}$. Moreover, its maximum values or, respectively, the minimum boring speed were recorded in sections of wells drilled in safety-relevant areas, where the core was not divided into discs. Conversely, where the core was intensively divided into disks, the drillability decreased noticeably.

The numerical values of these parameters, averaged over all wells within the respective 
zones, were 9.5 and $4 \mathrm{~min} / \mathrm{m}$, differing by almost 2.5 times.

Taking samples of sandstone in areas of wells with solid core, in laboratory conditions, we determined the limits of the strength of the samples and the strength coefficients.

The sandstone strength values calculated by the formula (1) by drillability in the areas of the massif in which the core was destroyed on the disks turned out to be $6.7-9$, which is on average 1.5 times less than in adjacent zones with a solid core.

After overworking of massif, the residual pressure of methane and the gas content of the rocks did not exceed $0.5 \mathrm{MPa}$ and $0.2 \mathrm{~m}^{3} / \mathrm{t}$, respectively. As the collapsed roofs of the rocks compacted, the stresses in the sandstone massif partially recovered and stabilized at $23 \mathrm{MPa}$.

It is known that with a decrease in the stress state of rocks from $100 \mathrm{MPa}$ to zero, their drillability decreases [8], i.e., the qualitative picture is the opposite of that recorded in the described experiments during partial unloading of the massif. This proves that the reason for the increase in drillability and strength of sandstones was their degassing, and not the change in the stress state of the environment.

\section{Conclusions}

The mechanical characteristics of outburst and outburst-safe sandstones differ noticeably among themselves. But these differences are clearly seen in the gas-saturated state of the rocks and are largely smoothed out when they are degassed. Sandstone strength in outburst zones is on average $f=8$, in outburst-safe $f=11$, i.e. it differs 1.4 times.

After degassing, the strength of outburst and outburst-safe sandstones is approximately the same. Thus, the results of experimental studies have shown that methane, like other fluids, reduces the strength of outburst sandstones.

This in particular can be explained why, when tested on degassed samples taken in outburst and outburst-safe zones, the differences in strength properties are not traced or expressed weakly, which leads to contradictory interpretations in assessing the causes of local zonality of emissions.

The fact that the change in the mechanical characteristics of outburst sandstones during their gas saturation and degassing occurs within the same limits indicates that mass transfer processes and the degree of gas saturation of the rocks affect the change in properties and are not accompanied by irreversible changes in the structure of the environment.

Decrease in strength and increase in deformation properties of rocks in a gas-saturated state testify that for their destruction smaller tension and energy value are required. This is one of the forms of influence of gas on outburst, which must be considered when studying the nature and mechanism of gas-dynamic phenomena and quantifying their parameters.

\section{References}

1. Nikolaev, N.I., Leusheva, E.L. (2014). Analiz sposobov ponizheniya tverdosti gornyih porod i metodik vybora poverhnostno-aktivnyih veschestv dlya povysheniya effektivnosti burovyh rabot, Vestnik PNIPU: Geologiya. Neftegazovoe i gornoe delo (12), 12-21

2. Voloshin, N.E. (2004) Aktualnye problemy dinamicheskih i gazodinamicheskih davleniy v shahtah, Donetsk: Vega-print, 24-31

3. Chubrikov, A.V., Rib, L.V. (2016). Razvitie i sovershenstvovanie polimernyh tehnologiy na ugolnyh shahtah Kuzbassa, Vestnik Sibirskogo gosudarstvennogo industrialnogo universiteta, 2(16), 3-6

4. Kulinich, V.S., Shevelev, G.A., Egorov, S.I. (1994). Metody i sredstva opredeleniya parametrov geomehanicheskogo sostoyaniya gazonosnogo porodnogo massiva. 


\section{Donetsk: TsBNTI}

5. Shmatovskiy, L.D. (2002). Opyt podgotovki i ispolzovaniya gidravlicheskogo oborudovaniya dlya otsenki napryazhennogo sostoyaniya ugleporodnogo massiva plasta $l_{l}$, Geotehnicheskaya mehanika [Geo-technical mechanics], Dnepropetrovsk (37), 104-109.

6. Haritonov, V.G. (2004). Geomehanicheskoe obosnovanie parametrov i realizatsiya tehnologii krepleniya gornyh vyrabotok ugolnyh shaht kanatnymi ankerami. Dissertatsiya na soiskanie stepeni kandidata tehnicheskih nauk, Kemerovo

7. Kulinich, V.S. (1978). Metod rascheta davleniya gaza v porodnom massive po krivoy ego nachalnogo narastaniya v skvazhine. Dnepropetrovsk: IGTM NASU (1501-78)

8. Shevelev, G.A., Kulinich, V.S. (1974). Burimost kak metod otsenki mehanicheskih svoystv vybrosoopasnyih zon v massive peschanika. Ugol [Coal] (12), 38-41 